\title{
Carbon shale combustion in the fluidized bed reactor
}

\author{
Małgorzata Olek $^{1}$, Stanisław Kandefer ${ }^{1}$, Wiesław Kaniowski ${ }^{1 *}$, Witold Żukowski ${ }^{2}$, Jerzy Baron ${ }^{2}$ \\ ${ }^{1}$ Cracow University of Technology, Faculty of Environmental Engineering, Institute of Thermal Engineering and Air \\ Protection, Warszawska 24, 31-155 Cracow, Poland \\ ${ }^{2}$ Cracow University of Technology, Faculty of Chemical Engineering and Technology, Institute of Inorganic Chemistry \\ and Technology, Warszawska 24, 31-155 Cracow, Poland \\ "Coresponding author: e-mail: wieslaw.kaniowski@gmail.com
}

\begin{abstract}
The purpose of this article is to present the possibilities of coal shale combustion in furnaces with bubbling fluidized bed. Coal shale can be autothermally combusted in the fluidized bed, despite the low calorie value and high ash content of fuel. Established concentrations of CO (500 ppm) and VOC $\left(30 \mathrm{mg} / \mathrm{m}^{3}\right)$ have indicated a high conversion degree of combustible material during combustion process. Average concentrations of $\mathrm{SO}_{2}$ and $\mathrm{NO}_{\mathrm{x}}$ in the flue gas were higher than this received from the combustion of high quality hard coal, $600 \mathrm{ppm}$ and $500 \mathrm{ppm}$, respectively. Optional reduction of $\mathrm{SO}_{2}$ and $\mathrm{NO}_{\mathrm{x}}$ emission may require the installation of flue gas desulphurization and de- $\mathrm{NO}_{\mathrm{x}}$ systems.
\end{abstract}

Keywords: shale coal, combustion, fluidized bed technology.

\section{INTRODUCTION}

Over the World, hard coal is the most important source of energy, its share in electricity production is approximately $40 \%$ and is growing ${ }^{1}$. Technical progress of coal beneficiation and combustion technology allows to use the low quality coal in the combustion plants. Currently it is possible to burn combustible materials with a high share of mineral constituents mined with the coal, which were previously classified as wastes. Coal shale, the fine-grained sedimentary rock, is an example of such material. The high content of non-combustible mineral matter and low calorific value was the reason for separating coal shale from the hard coal, in the flotation process, and depositing it into the dumps.

One of the most effective technologies which can be used in the process of thermal treatment of low calorific fuels, with a high content of the ash, is fluidized bed combustion. The suitability of the proposed technology for the combustion of high moisture and ash content material has been shown in the previous works ${ }^{2-6}$. Proper regulation of the fluidization process parameters (e.g. bed temperature, air excess, fuel mass flow) assure that the low quality fuels can undergo combustion autothermally. Thermal process which takes place in a fluidized bed reactor is intense but steady. High heat exchange coefficients help to maintain a uniform temperature throughout the bed. High thermal capacity of the bed, makes it possible to burn fuels with very variable calorific value. With an appropriate technical solution, heat recovery from the hot ash removed from the furnace, can be efficient ${ }^{6}$.

The intention of this work was to assess whether coal shale could be burned in a bubbling fluidised bed combustor, at atmospheric pressure and autothermal conditions, to obtain energy. The tests were aimed at determining technological parameters useful for the designing of shale combustion process and establishing guidelines for the construction of a full scale installation.

\section{EXPERIMENTAL}

The coal shale used in the tests was taken from the mine dumps "Makoszowy". Granulometric analysis of air-dry material was determined using a set of sieves, the results are shown in Figure 1.

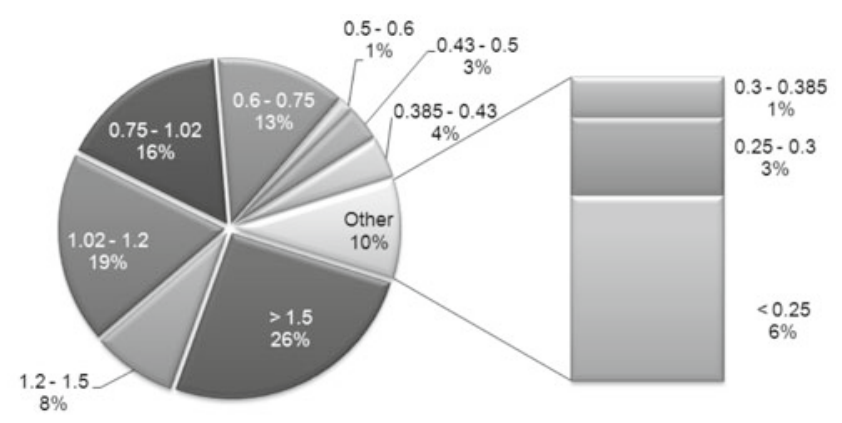

Figure 1. Fractional analysis of the test material

Approximately $69 \%$ of the material mass constituted fraction of the particle size more than $0.75 \mathrm{~mm}$, however, larger particles were easy to break down into fractions useful in the fluidised bed. A slight amount of fraction of dusty material was an additional effect of the material sticking during heap storage under moisture condition.

The tests were carried out on coal shale fraction of particle size 0.3 to $0.75 \mathrm{~mm}$. This granulation range was chosen in order to maintain the proper course of fluidization process in laboratory scale reactor. If the particles were too small, the flow rate of the fluidizing medium $(\sim 1 \mathrm{~m} / \mathrm{s})$ would be transported particles out of the reactor. Particles with a diameter of more than 0.75 $\mathrm{mm}$ could settle down on the level of a gas distributor.

The hygroscopic moisture, the content of the organic and ash fractions ${ }^{7-9}$, was determined for each fraction, the results have been collected in Table 1.

The average hygroscopic moisture of air-dry coal shale was not more than $1.1 \%$. The mean ash content of the analyzed material was $68 \%$. The percentage of ash in the material increased with decreasing particle size. The mean gross calorific value was $6540 \mathrm{~kJ} / \mathrm{kg}$.

Laboratory tests of the coal shale combustion were carried out using a system consisting of a fluidised bed reactor, $400 \mathrm{~mm}$ long, $96 \mathrm{~mm}$ in diameter, together with an automatic solid fuel feeder, ash removal system (dust chamber, cyclone) and a set of analytical instruments. A detailed scheme of the lab stand is given in an earlier 
Table 1. Analysis of the properties of each fraction of the coal shale

\begin{tabular}{|l|c|c|c|c|}
\hline Fraction, $\mathrm{mm}$ & $0.6-0.75$ & $0.5-0.6$ & $0.43-0.5$ & $0.385-0.43$ \\
\hline Weight loss in $105^{\circ} \mathrm{C}, \%$ & 0.9 & 1.18 & 1.25 & $0.3-0.385$ \\
\hline Weight loss in $550^{\circ} \mathrm{C}, \%$ & 34.08 & 30.29 & 29.17 & 0.97 \\
\hline Weight loss in $800^{\circ} \mathrm{C}, \%$ & 1.35 & 1.47 & 1.67 & 28.73 \\
\hline Ash content in dry mass, $\%$ & 64.25 & 67.86 & 68.78 & 1.49 \\
\hline
\end{tabular}
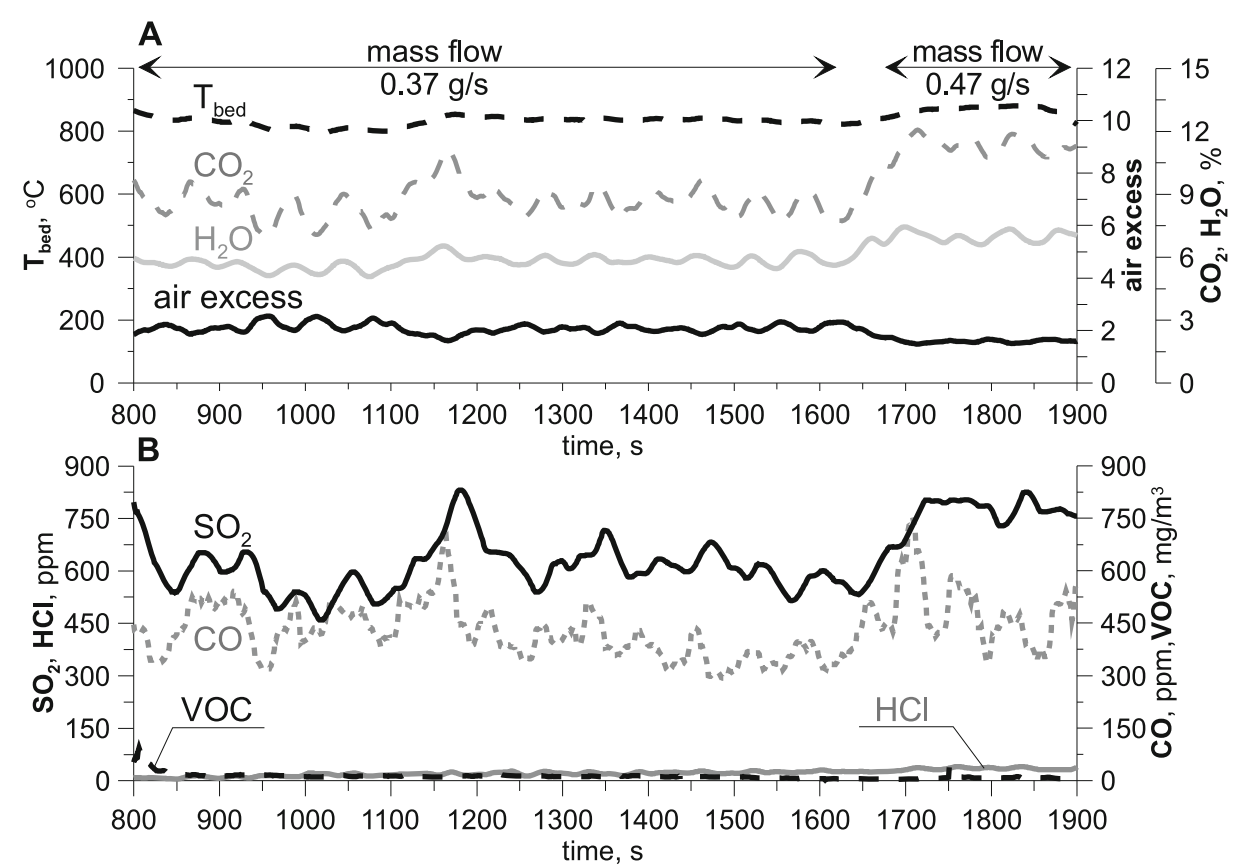

Figure 2. Changes in the fluidized bed temperature and the concentrations of selected components of the flue gases during the combustion of coal shale
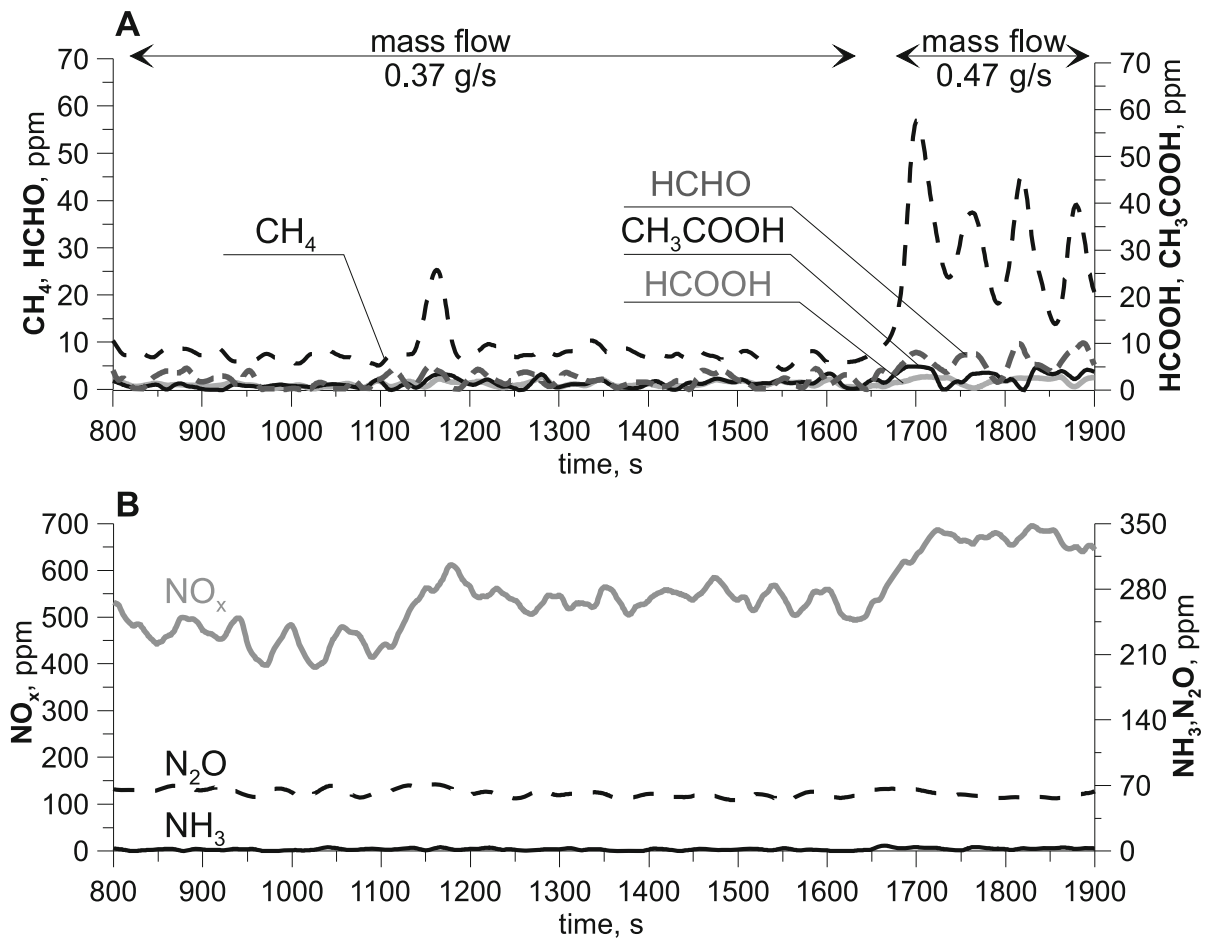

Figure 3. Changes in the concentrations of degasification products of coal shale and the gaseous nitrogen compounds

work $^{\mathbf{1 0}}$. The basic parameters of the combustion process, the concentration of $\mathrm{O}_{2}$ and bed temperature, were controlled by using electrochemical sensor (ECOM-SG Plus analyzer) and $\mathrm{NiCr}-\mathrm{Ni}$ thermocouples placed in the bed 20 and $50 \mathrm{~mm}$ above the gas distributor. Concentrations of the main combustion products $\left(\mathrm{CO}_{2}, \mathrm{H}_{2} \mathrm{O}\right)$, the main pollutants $\left(\mathrm{NO}_{\mathrm{x}}, \mathrm{SO}_{2}\right)$ and other combustion products $\left(\mathrm{CO}, \mathrm{C}_{\mathrm{x}} \mathrm{H}_{\mathrm{y}}, \mathrm{CH}_{4}, \mathrm{HCHO}, \mathrm{HCOOH}, \mathrm{CH}_{3} \mathrm{CO}-\right.$
$\mathrm{OH})$ were monitored via a set of analyzers. The basic element of the analytic set was a Gasmet ${ }^{\mathrm{TM}}$ DX-4000 IR spectrum analyzer. In addition, the analyzer, the J.U.M. model 3-200, controlled VOC concentration, and analyzer PG-250 monitored the concentration of $\mathrm{NO}_{\mathrm{X}}$. The concentration of VOCs, was determined by using a flame-ionization (FID) and $\mathrm{NO}_{\mathrm{x}}$ by chemiluminescence 
(CLA) method. The flue gases were sampled from the freeboard $300 \mathrm{~mm}$ above the distributor.

The initial bed material used in the experiments was $100 \mathrm{~g}$ quartz sand, the particle size 0.15 to $0.25 \mathrm{~mm}$. These fractions sizes were selected due to ease in sieving the sand from the ashes obtained from burning coal shale. The volumetric flow rate of air was kept constant, at 1.67 $\mathrm{dm}^{3} / \mathrm{s}$. The combustion process was started using mixture of air and LPG and brought to steady operation. When bed temperature was stabilized at $850^{\circ} \mathrm{C}$, the gaseous fuel was replaced by the coal shale, whose mass flow was $0.37 \mathrm{~g} / \mathrm{s}$ or $0.47 \mathrm{~g} / \mathrm{s}$.

\section{RESULTS AND DISCUSSION}

During the entire experiment, the coal shale was burned autothermally. Fuel weight loss during the combustion was $\sim 30 \%$, which confirms the high content of noncombustible parts in the tested material. The bulk density of the coal shale was $935.48 \mathrm{~kg} / \mathrm{m}^{3}$ while for the ashes, with a diameter greater than $0.3 \mathrm{~mm}$, it was 762.5 $\mathrm{kg} / \mathrm{m}^{3}$. The ash obtained from the combustion of coal shale have a form other than the ash which was obtained from coal combustion in the fluidized bed technique. Its bulk density is lower which indicates that the structure of noncombustible part of test material is more porous.

Figures 2 and 3 illustrate the bed temperature and concentrations of the selected constituents of the flue gases as a functions of combustion test time. In order to assess the quality of combustion process the concentrations of carbon monoxide and volatile organic compounds (VOCs) were measured. In the course of the tests the concentration of VOC in the flue gases did not exceed $30 \mathrm{mg} / \mathrm{m}^{3}$. Analysis of volatile organic compounds was extended to devolatilization products, whose presence in freeboard indicates incomplete combustion. The concentration of formaldehyde, formic acid and acetic acid has been determined. The concentration of these substances did not exceed 5 ppm, which means that the process of devolatilization and combustion took place entirely in the bed. Moderate concentration of $\mathrm{CO}$ was the result of rapid cooling of flue gases in the space above the bed (in the place where gases are sampled the reactor is not isolated).

After increasing the mass flow of fuel by $27 \%$, the excess air coefficient decreased from 2 to 1.5. An increase of $\mathrm{CO}$ concentration by $26 \%$ was observed, while VOC concentration did not increased. Among all, only $\mathrm{CH}_{4}$ concentration increased to $35 \mathrm{ppm}$ (Fig. 3A).

The combustible parts of the tested material were characterized by a high amount of bound nitrogen and sulfur, thus the average concentrations of $\mathrm{SO}_{2}$ and $\mathrm{NO}_{\mathrm{x}}$ in the flue gas were 600 ppm (Fig. 2B) and 500 ppm (Fig. 3B), respectively. The combustion of the coal shale in a fluidised bed makes it possible to carry out the desulphurisation process in the combustion chamber. By adding limestone with the fuel, the high concentration of $\mathrm{SO}_{2}$ can be limited. According to Anthony et al. during coal combustion, to obtain above $80 \%$ desulphurisation, 2-3 fold excess of the limestone sorbent should to be used $^{11}$. Stoichiometric binding of $1 \mathrm{~kg}$ of $\mathrm{SO}_{2}$, requires the introduction of $0.875 \mathrm{~kg} \mathrm{CaO}$ in a form of limestone.

\section{CONCLUSIONS}

Stable autothermal combustion of coal shale in FB reactor leads to a conclusion that in relation to conventional solid fuels it may be used as an alternative energy sources. Due to higher ash content, heat recuperator should be included in the construction of the combustion furnace. The full-scale technical application will also require the installation of flue gas desulphurization system. In the fluidized bed technology, the material of the bed can be modified by adding a calcium sorbent to combine $\mathrm{SO}_{2}$. The reduction of emission of $\mathrm{NO}_{\mathrm{x}}$ will be possible by an appropriate organization of the combustion process, using for example, air staging, reburning or selective non catalytic nitrogen oxides reduction by $\mathrm{NH}_{3}$ or other reducing agent.

A large amount of fine particles of ash highlight the necessity of use fly ash removal system, in the dust collecting chamber, the battery of cyclones or the bag filter.

\section{LITERATURE CITED}

1. Klank, M. (2010). The future of coal - a new look at its use, Energy Policy, 10(1), 41-49 (in Polish).

2. Kandefer, S. (1989). Fluidized bed combustion of low-grade fuels and waste, Cracow: Cracow University of Technology Publisher, (in Polish).

3. Baron, J., Bulewicz, E.M., Kandefer, S., Pilawska, M. \& Żukowski, W. (2006). Environmentally-friendly Use of Waste Biomass in Protected Areas. Environ. Prot. Eng. 32 (1), 35-40.

4. Porzuczek, J. (2012). Optimization of the fluidized bed boilers operation in nonstationary states. Cracow: Cracow University of Technology Publisher, monograph No. 405 (in Polish).

5. Kandefer, S., Juryś, C., Bulewicz, E.M., Dyczewski, R. \& Dyśko, J. (1989). Patent Republic of Poland No. 164249. Patent Office of Republic of Poland.

7. Polish Committee for Standardization. (1980). Polish standard: Solid fuels. Determination of moisture content. PNG-04511:1980. Warsaw.

8. Polish Committee for Standardization. (2011). Polish standard: Characterization of waste - Determination of loss on ignition of the waste, sludge and sediments. PN-EN-15169:2011. Warsaw.

9. Polish Committee for Standardization. (1980). Polish standard: Solid fuels. Determination of ash by weight. PN-G-04512:1980. Warsaw.

10. Żukowski, W., Baron, J., Kowarska, B. \& Zabagło, J. (2010). $\mathrm{N}_{2} \mathrm{O}$ conversion in active and chemically inert fluidized bed. Environ. Prot. Eng. 36(3), 15-32. http://epe.pwr.wroc. pl/2010/zukowski_3-2010.pdf

11. Anthony, E.J. \& Granatstein, D.L. (2001). Sulfation phenomena in fluidized bed combustion systems. Progress in Energy and Combustion Science, 27 (2), 215-236. DOI:10.1016/ S0360-1285(00)00021-6. 